\title{
The Wish Machine
}

\section{Chrysanne Stathacos}

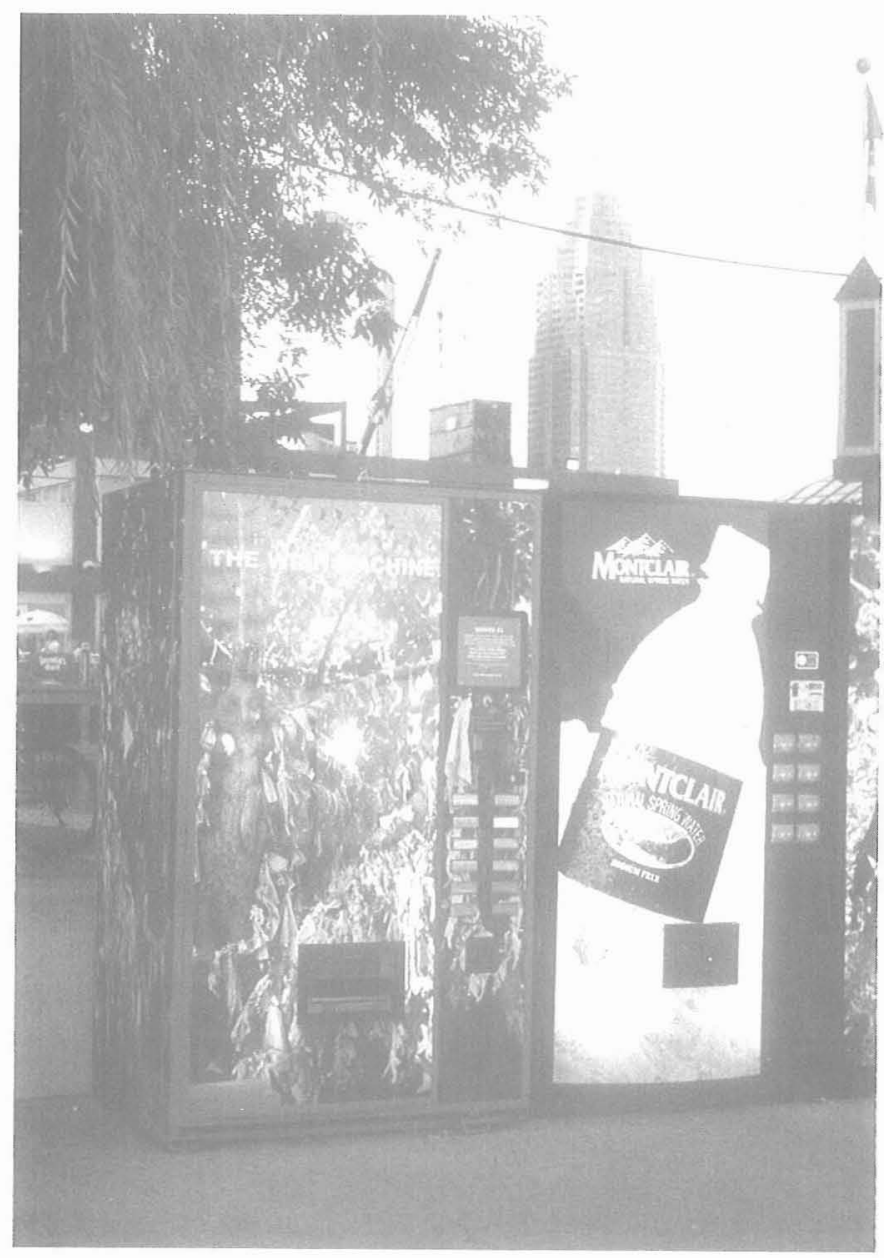

